\title{
Evaluation of Drought Tolerant Rice Cultivars Using Drought Tolerant Indices under Water Stress and Irrigated Condition
}

\author{
Mandeep Adhikari 1,2*, Nav Raj Adhikari' ${ }^{1}$, Subarna Sharma1,2, Janmajaya Gairhe ${ }^{3}$, \\ Rishi Ram Bhandari ${ }^{4}$, Sakshi Paudel ${ }^{5}$ \\ ${ }^{1}$ Department of Plant Breeding, Institute of Agriculture and Animal Science, Tribhuvan University, Kirtipur, Nepal \\ ${ }^{2}$ Department of Biological Sciences, Mississippi State University, Starkville, Mississippi State, USA \\ ${ }^{3}$ Department of Soil Science and Agri-Engineering, Institute of Agriculture and Animal Science, Tribhuvan University, Kirtipur, Nepal \\ ${ }^{4}$ Department of Entomology and Plant Pathology, Auburn University, Auburn, Alabama, USA \\ ${ }^{5}$ Prithu Technical College, Institute of Agriculture and Animal Science, Tribhuvan University, Dang, Nepal \\ Email: *mandy.deep123@gmail.com
}

How to cite this paper: Adhikari, M., Adhikari, N.R., Sharma, S., Gairhe, J., Bhandari, R.R. and Paudel, S. (2019) Evaluation of Drought Tolerant Rice Cultivars Using Drought Tolerant Indices under Water Stress and Irrigated Condition. American Journal of Climate Change, $\mathbf{8}$, 228-236.

https://doi.org/10.4236/ajcc.2019.82013

Received: March 11, 2019

Accepted: June 3, 2019

Published: June 6, 2019

Copyright $\odot 2019$ by author(s) and Scientific Research Publishing Inc. This work is licensed under the Creative Commons Attribution International License (CC BY 4.0).

http://creativecommons.org/licenses/by/4.0/

(c) $)$ OP Open Access

\begin{abstract}
Drought is the most critical abiotic factor reducing rice yield in rainfed and drought prone areas. Majority of rice cultivated area in south Asia are under rainfed, where water stress at any of the critical growth stage causes sharp decline in yield. Research was conducted in western Nepal at farmers field around the close vicinity of Regional Agriculture Research Center (RARS) Nepalgunj. Ten different rice cultivars were evaluated under drought stress and non-stress condition during the year 2017 to identify superior stress tolerant cultivars. Different drought tolerance indices like stress tolerance (TOL), Stress tolerance index (STI), Stress susceptibility index (SSI), were tested in screening superior rice cultivars. Significant reduction in mean grain yield was observed under drought stress in all rice cultivars under the study. The rice cultivars with high STI values and low TOL and SSI were identified as superior drought tolerant cultivars. Based on results of different tolerance indices, Sukha series of rice, Sukha Dhan 1-6 and Radha-4 showed low TOL and SSI and high STI values and were identified as drought tolerant cultivars. The present study reveals that selection based on drought tolerance indices can be an efficient tool in identification of superior drought tolerant cultivars with higher yield and stability.
\end{abstract}

\section{Keywords}

Rice, Drought Stress, Drought Tolerance Indices, Drought Tolerant Cultivars 


\section{Introduction}

Rice (Oryza Sativa) is staple food for more than half of the world's population. [1]. About $90 \%$ of the global rice is produced as well as consumed in Asia [2]. Rice supplies more than $80 \%$ of the calorie and $75 \%$ of the protein consumed by people residing in Asia [3]. Drought is considered as the major yield reducing factor in rain-fed areas of Southeast Asia, affecting more than 23 million ha area [4]. In Asia, around $50 \%$ of the rice cultivated area is rainfed. Although rapid progress has been attained in breeding of irrigated rice, there is little gain in rainfed rice ecosystem over the last few decades with significantly low yield potential of 1.5 to $2.5 \mathrm{t} \cdot \mathrm{ha}^{-1}$ [5]. Rice is highly sensitive to soil moisture deficit during its critical growth stages, mostly during pre-flowering and grain filling stages. Losses due to drought stress are most severe in south Asian countries mainly in Nepal, India, Bangladesh and Myanmar. In Nepal, rainfed rice accounts for $57 \%$ of the total area under rice cultivation in the country. Rice was grown in about 1.42 million hectors of land; approximately 0.8 million hectors are estimated to be drought-prone [6]. Most of the traditional as well as high yielding varieties cultivated in Nepal are highly susceptible to drought. Farmers are seeking for better cultivars that can perform well under stress condition, and in the eyes of farmers, drought resistant cultivars are the ones that have better yield potential and stability than various other available cultivars specifically under water scarce conditions [7]. The higher frequency and intensity of drought spells necessitates development of rice cultivars, which can survive under water deficit at critical growth stages and quickly recover after drought, by rapid growth upon the availability of soil moisture [8].

Under severe drought stress, yield declines in rice range between $65 \%-85 \%$ as compared to non-stress conditions [9]. There are various indices to determine drought tolerance such as stress tolerance level (TOL), stress tolerance index (STI), stress susceptibility index (SSI) and drought tolerant efficiency (DTE) that can be used as an indicator to identify superior cultivars that can perform better in stress-prone environments [10] [11]. Mean yield and relative yield performance are the most extensively used parameters for selecting genotypes in stress-prone environments comparing the yield and yield potential under the stressed and irrigated conditions [10] [11]. Pinter et al. (1990) [12], and Kumar et al. (2014) [10] found relative grain yield to be a useful criterion for assessing drought response of wheat genotypes. The ability of any crop cultivars to perform reasonably well in drought stressed environments is noted as a key indicator for crop stability. Different authors have proposed that combined results of high yield stability and high relative yield can be reliable selection criteria for characterizing genotypic performance under varying degrees of moisture stress [12]. The objective of present study was to identify rice cultivars having high yield potential and stability under drought stress conditions by analyzing drought tolerance indices during its critical growth stages under rainfed condition of western Nepal. 


\section{Methods and Methodology}

\subsection{Experimental Details}

Research was conducted in Western Nepal at the Farmer's field around the vicinity of Regional Agriculture Research Station (RARS) Nepalgunj. Geographically, it is located between at $81^{\circ} 37^{\prime \prime} \mathrm{E}$ longitudes and $28^{\circ} 06^{\prime \prime} \mathrm{N}$ latitude and an altitude of 181 meters above mean sea level. Soil of the research site is sandy to silty loam, poor in organic carbon and available nitrogen but medium in available phosphorus $\left(\mathrm{P}_{2} \mathrm{O}_{5}\right)$ and potassium $\left(\mathrm{k}_{2} \mathrm{O}\right) \mathrm{pH}$ varies from 7.2 - 7.5. The field experiment was conducted in Completely Randomized Block Design (RCBD). There were two conditions, fully irrigated and drought. Each condition was replicated 3 times. Each replication consists of ten treatments of plot size $3.6 \times 5 \mathrm{~m}^{2}$. Each plot consisted of 18 rows with spacing of $20 \mathrm{~cm}$ between rows and $20 \mathrm{~cm}$ spacing between plants. There was $0.5 \mathrm{~m}$ between blocks and plots.

Irrigated Condition: Ten varieties, Sukha-3 as positive check and Samba Mansuli Sub-1 as negative check were used

Unirrigated (Drought stress) Condition: Ten varieties, Samba Mansuli sub-1 as positive check and Sukha-3 as negative checks were used. The pedigree and yield potential of tested cultivars are presented in Table 1.

Table 1. Pedigree and characteristics of tested cultivars.

\begin{tabular}{|c|c|c|c|c|c|}
\hline Cultivars & Parents & $\begin{array}{c}\text { Year } \\
\text { Released }\end{array}$ & Origin & $\begin{array}{c}\text { PM } \\
\text { (days) }\end{array}$ & $\begin{array}{c}\text { Yield } \\
\text { potential } \\
\left(\mathrm{t} \cdot \mathrm{ha}^{-1}\right)\end{array}$ \\
\hline Sukha Dhan-1 & IR55419*2/WAYRAREM & 2011 & IRRI & 125 & $3.2-4.2$ \\
\hline Sukha Dhan-2 & IR55419*2/WAYRAREM & 2011 & IRRI & 125 & $2.3-3.5$ \\
\hline Sukha Dhan-3 & IR55419*2/WAYRAREM & 2011 & IRRI & $122-125$ & $2.5-3.6$ \\
\hline Sukha Dhan-4 & $\begin{array}{l}\text { IR77298-14-1-2-10/ } \\
\text { IR 77298-5-6-195 }\end{array}$ & 2014 & IRRI & 125 & $2.7-4.0$ \\
\hline Sukha Dhan-5 & $\begin{array}{l}\text { IR72022-46-2-3-3-2/ } \\
\text { IR833888B-B108-3 }\end{array}$ & 2014 & IRRI & 125 & $3.2-4.2$ \\
\hline Sukha Dhan-6 & $\begin{array}{l}\text { IR 72022-46-2-3-3-2/ } \\
\text { IR 57514-PMI 5-B-1-2 }\end{array}$ & 2011 & IRRI & $120-125$ & $3-4$ \\
\hline Radha-4 & $\begin{array}{l}\text { IRGC 11778/ } \\
\text { IR 2071-625-1 }\end{array}$ & 1994 & IRRI & 125 & 3.2 \\
\hline Loktantra & ${ }^{*} \mathrm{NR} 1487-2-1-2-2-1-1$ & 2006 & NARC & 130 & 3.6 \\
\hline Bindeshwori & R126-42-5/IR2061-213 & 2006 & NARC & 128 & 4.0 \\
\hline $\begin{array}{c}\text { Samba Mansuli } \\
\text { Sub-1 }\end{array}$ & ${ }^{\#}$ IR07F287 & 2011 & IRRI & 150 & $4.5-5$ \\
\hline
\end{tabular}




\subsection{Selection of Drought Tolerant Indices}

Several drought indices have been suggested based on various mathematical relationship between yield under drought stress and non-stressed conditions. These indices vary with resistance and susceptibility of genotypes [11]. If $\left(\mathrm{Y}_{\mathrm{i}}\right)_{\mathrm{S}}$ denotes yield of $i^{\text {th }}$ genotype under stress condition, $\left(Y_{i}\right)_{N S}$ denotes Yield of $i^{\text {th }}$ genotype under non-stress condition, Ys denotes total mean yield under stress condition and $\mathrm{Y}_{\mathrm{NS}}$ denotes total mean yield under non-stress condition. Rosielle and Hamblin (1981) [14] defined stress tolerance (TOL) as the differences in yield between stress and non-stress environments. i.e. $\mathrm{TOL}=\left(\mathrm{Y}_{\mathrm{i}}\right)_{\mathrm{NS}}-\left(\mathrm{Y}_{\mathrm{i}}\right)_{\mathrm{s}}$. Higher value of TOL indicates, susceptibility of a given cultivar. Hosssain et al. (1990) [15] defined mean productivity index MPI as the average of $\left(\mathrm{Y}_{\mathrm{i}}\right)_{\mathrm{NS}}$ and $\left(\mathrm{Y}_{\mathrm{i}}\right)_{s}$. Ramirez, Vallejo and Kelly (1998) defined geometric mean productivity (GMP) as the square root of product of yield under stress and non-stress environment: GMP $=\sqrt[2]{\left(\mathrm{Y}_{\mathrm{i}}\right)_{\mathrm{NS}}-\left(\mathrm{Y}_{\mathrm{i}}\right)_{\mathrm{S}}}$. GMP is useful and more efficient when breeding objective is directed toward testing performance under favorable vs unfavorable environment, in account with variability in drought intensity and years (Raman et al., 2012). Bouslama and Schapaugh, (1984) [16] defined, yield stability index, (YSI) as the ratio of mean yield of genotypes under stress environment to that of non-stress environment as, $\mathrm{YSI}=\left(\mathrm{Y}_{\mathrm{i}}\right)_{\mathrm{s}} /\left(\mathrm{Y}_{\mathrm{i}}\right)_{\mathrm{NS}}$. The value close to 1 indicates higher stability of genotypes under the stress environment as compared to non-stress environment. Fernandez (1992) [17] defined a stress tolerance index $(\mathrm{STI})$ as, $\mathrm{STI}=\frac{\left(\mathrm{Y}_{\mathrm{i}}\right)_{\mathrm{NS}} *\left(\mathrm{Y}_{\mathrm{i}}\right)_{\mathrm{S}}}{\left(\mathrm{Y}_{\mathrm{i}}\right)_{\mathrm{NS}}^{2}}$, this can be used to identify genotypes that perform well under both stress and non-stress conditions. Fisher and Maurer (1978) [18] proposed stress susceptibility index (SSI), that assess the reduction in yield caused by unfavourable vs favourable environments, SSI is expressed as $\left.\left[1-\mathrm{Y}_{\mathrm{i}}\right)_{\mathrm{S}} /\left(\mathrm{Y}_{\mathrm{i}}\right)_{\mathrm{NS}}\right] / \mathrm{SI}$ where, $\mathrm{SI}$ is the stress intensity, estimated as, $\mathrm{SI}=$ $\left[1-\left(\mathrm{Y}_{\mathrm{i}}\right)_{S} /\left(\mathrm{Y}_{\mathrm{i}}\right)_{\mathrm{NS}}\right]$. Lower SSI values indicate lower difference in yield across stress levels, i.e. more tolerance to drought. SSI is exclusively used to identify genotypes with yield stability in moisture deficit environment [11] [19].

\subsection{Temperature and Precipitation}

During last few years, the precipitation has substantially reduced. In absence of artificial irrigation and uneven rainfall, rice cultivated in western Nepal faces mid-season drought and late season drought. The monthly temperature and precipitation of Regiional Agriculture Research Center (RARS), Nepalgunj is presented in Figure 1. The weather data of RARS, Nepalgunj reflects the micro climate condition of research site since, research field is located at the close vicinity of research station. During the crop growth period (June to October 2017) the mean maximum monthly temperature was 37.04 during June and the mean minimum monthly temperature was $18.8^{\circ} \mathrm{C}$ during October. The rice crop cultivated in western terai belt of Nepal during year 2017 received maximum precipitation during the month of August i.e. 497.8 with gradual decline in tempera- 
ture and rainfall during Sept. and Oct.

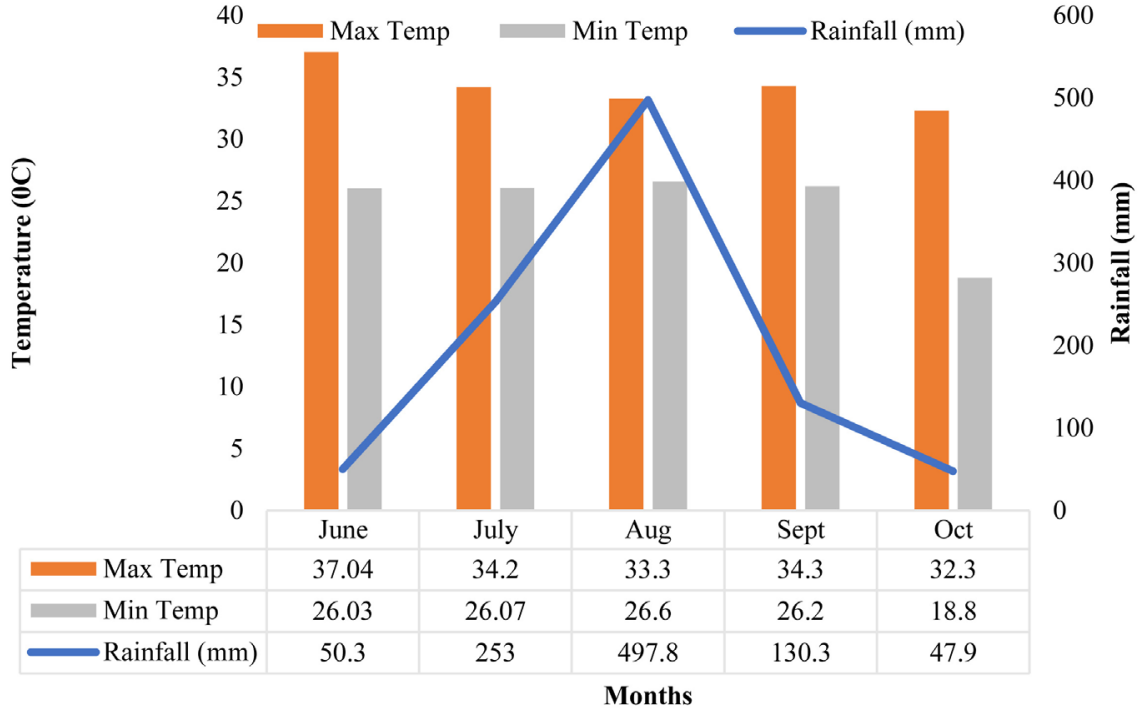

Figure 1. Weather data of RARS Nepalgunj during crop growing period. (Source: RARS Banke, 2017).

\subsection{Statistical Analysis}

Statistical analysis was carried out using, R-3.3.0. Analysis of variance was performed for randomized complete block design (RCBD). Duncan's Multiple Range Test (DMRT) was used to compare the differences among key parameters of drought tolerance indices at $\mathrm{P}<0.05$ level of significance.

\section{Result and Discussion}

\subsection{Drought Tolerance Indices}

The drought tolerant indices for ten different rice cultivars are presented in $\mathrm{Ta}$ ble 2. Significant difference was observed between the mean grain yield under stress and non-stress condition for all cultivars indicating, considerable difference in performance between two different conditions. The production was substantially higher in non-stress environment for every cultivar as compared to the yield obtained under stress environment. The mean yield ranged from $9.18 \mathrm{t} \cdot \mathrm{ha}^{-1}$ to $6.17 \mathrm{t} \cdot \mathrm{ha}^{-1}$ under the non-stress condition, while it ranged from $5.70 \mathrm{t} \cdot \mathrm{ha}^{-1}$ to $3.71 \mathrm{t} \cdot \mathrm{ha}^{-1}$ under the stress environment. Sukha Dhan-3 was the top performer under the stress condition followed by Sukha Dhan-6 and Radha 4. Although, Samba Mansuli Sub-1 had exceptionally higher yield under non-stress, its yield declined by $60 \%$ under stress environment. Loktantra and Bideshwori, other two superior performers under the non-stress environment had 2 -fold decline in yield under the stress-environment. The cultivars performing best under non-stress condition performed poor in terms of mean yield under the stress condition, which is agrees with the findings reported by (Kumar et al., 2014 and Raman et al., 2012) [11] [20]. 
Table 2. Mean grain yield and drought tolerance indices of rice cultivars in response to drought stress and non-stress condition.

\begin{tabular}{ccccccccccc}
\hline & & & \multicolumn{5}{c}{ Drought Tolerant Indices } \\
\cline { 7 - 10 } Cultivar & $\mathrm{Y}_{\text {NS }}$ & $\mathrm{Y}_{\mathrm{S}}$ & TOL & STI & MP & GMP & YSI & SSI & YI \\
\hline Sukha Dhan-1 & $6.47^{\mathrm{cd}}$ & $5.04^{\mathrm{c}}$ & $1.43^{\mathrm{a}}$ & $0.27^{\mathrm{ab}}$ & $5.76^{\mathrm{bcd}}$ & $3.39^{\mathrm{bc}}$ & $0.77^{\mathrm{ab}}$ & $0.54^{\mathrm{bc}}$ & $0.92^{\mathrm{d}}$ \\
Sukha Dhan-2 & $6.28^{\mathrm{d}}$ & $4.34^{\mathrm{d}}$ & $1.93^{\mathrm{a}}$ & $0.27^{\mathrm{ab}}$ & $5.31^{\mathrm{cd}}$ & $3.25^{\mathrm{c}}$ & $0.69^{\mathrm{c}}$ & $0.40^{\mathrm{a}}$ & $1.19^{\mathrm{ab}}$ \\
Sukha Dhan-3 & $7.18^{\mathrm{bc}}$ & $5.70^{\mathrm{a}}$ & $1.48^{\mathrm{a}}$ & $0.24^{\mathrm{ab}}$ & $6.44^{\mathrm{a}}$ & $3.59^{\mathrm{a}}$ & $0.79^{\mathrm{a}}$ & $0.56^{\mathrm{c}}$ & $0.92^{\mathrm{de}}$ \\
Sukha Dhan-4 & $6.82^{\mathrm{cd}}$ & $5.11^{\mathrm{bc}}$ & $1.71^{\mathrm{a}}$ & $0.25^{\mathrm{ab}}$ & $5.97^{\mathrm{ab}}$ & $3.45^{\mathrm{ab}}$ & $0.74^{\mathrm{abc}}$ & $0.38^{\mathrm{a}}$ & $1.21^{\mathrm{a}}$ \\
Sukha Dhan-5 & $6.17^{\mathrm{d}}$ & $4.35^{\mathrm{d}}$ & $1.82^{\mathrm{a}}$ & $0.27^{\mathrm{a}}$ & $5.26^{\mathrm{d}}$ & $3.24^{\mathrm{c}}$ & $0.70^{\mathrm{bc}}$ & $0.41^{\mathrm{ab}}$ & $1.07^{\mathrm{c}}$ \\
Sukha Dhan-6 & $7.21^{\mathrm{bc}}$ & $5.63^{\mathrm{ab}}$ & $1.57^{\mathrm{a}}$ & $0.24^{\mathrm{b}}$ & $6.42^{\mathrm{a}}$ & $3.58^{\mathrm{a}}$ & $0.78^{\mathrm{ab}}$ & $0.46^{\mathrm{ab}}$ & $0.88^{\mathrm{def}}$ \\
Loktantra & $8.91^{\mathrm{a}}$ & $4.15^{\mathrm{de}}$ & $4.76^{\mathrm{c}}$ & $0.16^{\mathrm{cd}}$ & $6.53^{\mathrm{a}}$ & $3.61^{\mathrm{a}}$ & $0.46^{\mathrm{de}}$ & $0.98^{\mathrm{de}}$ & $1.08^{\mathrm{bc}}$ \\
Bindeshwori & $7.71^{\mathrm{b}}$ & $3.77^{\mathrm{de}}$ & $3.93^{\mathrm{b}}$ & $0.19^{\mathrm{c}}$ & $5.74^{\mathrm{bcd}}$ & $3.38^{\mathrm{bc}}$ & $0.48^{\mathrm{d}}$ & $0.94^{\mathrm{d}}$ & $0.80^{\mathrm{ef}}$ \\
Radha-4 & $6.64^{\mathrm{cd}}$ & $5.22^{\mathrm{abc}}$ & $1.42^{\mathrm{a}}$ & $0.26^{\mathrm{ab}}$ & $5.93^{\mathrm{abc}}$ & $3.44^{\mathrm{ab}}$ & $0.78^{\mathrm{ab}}$ & $0.39^{\mathrm{a}}$ & $1.10^{\mathrm{abc}}$ \\
Samba Mansuli Sub-1 & $9.18^{\mathrm{a}}$ & $3.71^{\mathrm{e}}$ & $5.47^{\mathrm{c}}$ & $0.15^{\mathrm{d}}$ & $6.45^{\mathrm{a}}$ & $3.59^{\mathrm{a}}$ & $0.40^{\mathrm{e}}$ & $1.09^{\mathrm{e}}$ & $0.78^{\mathrm{f}}$ \\
Test of Sig. & $* * *$ & $* * *$ & $* * *$ & $* * *$ & $* * *$ & $* * *$ & $* * *$ & $* * *$ & $* * *$ \\
Grand Mean & 7.26 & 4.7 & 2.55 & 0.23 & 5.98 & 3.45 & 0.66 & -0.61 & 1 \\
LSD & 0.78 & 0.5 & 0.71 & 0.029 & 0.55 & 0.16 & 0.07 & 0.13 & 0.1 \\
EMS & 0.212 & 0.08 & 0.172 & 0.00029 & 0.1 & 0.0089 & 0.0017 & -0.005 & 0.003 \\
CV \% & 6.34 & 6.28 & 16.22 & 7.29 & 5.43 & 2.73 & 6.19 & -12.3 & 6.2 \\
\hline & & & & & & & & &
\end{tabular}

Least TOL value was recorded in Radha-4 (1.42) followed by Sukha Dhan-1, Sukha Dhan-3 and Sukha Dhan-6, whereas, Samba Mansuli Sub-1 (5.47) and Loktantra (4.76) exhibited higher TOL value. Lower value of TOL (stress tolerance) indicates, higher stress tolerant ability of given cultivar. The results of this study are in good agreement with the earlier findings reported by (Raman et al., 2012; Singh et al., 2018) [11] [21].

Stress Susceptibility index (SSI) precisely evaluates the yield reduction caused by unfavorable conditions as compared to favorable environments. Lower the value of SSI, higher will be the yield stability. Cultivars with less fluctuation in mean yield show lower SSI and higher stability in different environment. Sukha Dhan-4 exhibited least SSI with value 0.38 followed by Radha- 4 (0.39) and Sukha Dhan-2 (0.40) while, Samba Mansuli Sub-1 had higher SSI (1.09). The SSI of Loktantra and Bindeshwori were close to 1 . Cultivars with low SSI values can be considered as drought tolerant (Chauhan et al., 2007) since, they exhibit smaller yield reductions under water stress as compared to irrigated conditions. Based on the value and direction of desirability ranking was done for different cultivars as highly drought tolerant (SSI < 0.5), moderately drought tolerant (SSI: 0.5 0.75 ), drought tolerant (SSI: $0.75-0.1$ ) and drought susceptible (SSI > 1). Drought indices: TOL and SSI are useful parameters for identifying genotypes that perform well in stress environment (Kumar et al., 2014; Singh et al., 2018) [20] [21]. In this current research, cultivars with SSI close to 0.5 showed re- 
markably better performance for yield and stability under drought stress.

Stress tolerance index (STI) is used to compare the consistency and relative change in yield under stress and non-stress condition. Sukha series of rice and Radha- 4 showed higher values of STI as compared to other three varieties. Samba Mansuli sub-1 showed lowest STI value (0.15), which implies that it is highly susceptibility to drought stress. Similar result was obtained from the assessment of yield stability index (YSI) and Yield Index (YI).

\subsection{Correlation among Drought Indices and Yield}

Grain Yield under the stress condition (Ys) and non-stress condition (Yp) (Table 3) were found non-significant and negatively correlated indicating that cultivars with high yield potential under favorable environment does not anticipate superior yield under the stress environment. The weak association between Yp and Ys was reported in wheat by Anwar et al. (2011) [22]. Grain yield under the non-stress (Yp) had positive and significant correlation with MP and TOL whereas, association of Yp was significantly negative for STI, YSI and SSI. The grain yield under the stress (Ys) exhibited positive and significant association with GMP, STI, YSI, YI, and SSI. Similar findings for Ys with GMP, STI and MP were reported by Mau et al. (2019) [23]. Negative correlation was observed for TOL with YSI, STI, GMP and SSI. Raman et al. (2012) [11] reported similar results for correlation of TOL with YSI, STI and GMP. A perfect positive correlation was exhibited by YSI, STI and SSI among each other. This offers a choice for researcher to choose one among these drought indices and can be used interchangeably during selection. Mau et al. (2019) [23] had also reported for interchangeable drought indices in rice.

Table 3. Correlation among drought indices and yield (Yp and Ys).

\begin{tabular}{cccccccccc}
\hline & Yp & Ys & MP & GMP & STI & TOL & YSI & YI & SSI \\
\hline Yp & 1 & & & & & & & \\
Ys & -0.488 & 1 & & & & & & \\
MP & $0.736^{*}$ & 0.231 & 1 & & & & & & \\
GMP & 0.361 & $0.637^{*}$ & $0.896^{* *}$ & 1 & & & & & \\
STI & $-0.836^{* *}$ & $0.883^{* *}$ & -0.247 & 0.203 & 1 & & & & \\
TOL & $0.911^{* *}$ & $-0.805^{* *}$ & 0.391 & -0.056 & $-0.986^{* *}$ & 1 & & & \\
YSI & $-0.836^{* *}$ & $0.883^{* *}$ & -0.247 & 0.203 & $1.000^{* *}$ & $-0.986^{* *}$ & 1 & & \\
YI & -0.487 & $1.000^{* *}$ & 0.233 & $0.638^{*}$ & $0.883^{* *}$ & $-0.804^{* *}$ & $0.883^{* *}$ & 1 & \\
SSI & $-0.836^{* *}$ & $0.883^{* *}$ & -0.247 & 0.203 & $1.000^{* *}$ & $-0.986^{* *}$ & $1.000^{* *}$ & $0.883^{* *}$ & 1 \\
\hline
\end{tabular}

${ }^{*}$ Correlation is significant at the 0.05 level (2-tailed). ${ }^{*}$ Correlation is significant at the 0.01 level (2-tailed).

\section{Conclusion}

This study concludes that, water stress during critical growth stage of rice significantly reduces rice yield in all cultivars. Further, it also indicates that selection based on drought tolerance indices can be efficient tool in identification of 
superior drought tolerant cultivars with higher yield potential and stability. Based on results assessed from various parameters of drought tolerance indices, it revealed that Sukha series of rice cultivars, and Radha-4 possessed high level of drought tolerance since these cultivars exhibited low SSI and TOL with high STI values. These cultivars showed the highest yield under irrigated environment as well as performed better in drought stress conditions. Thus, these drought-tolerant rice cultivars can be better substitute of traditional, primitive and un-tested varieties in rainfed and drought-prone belts for rice cultivation.

\section{Conflicts of Interest}

The authors declare no conflicts of interest regarding the publication of this paper.

\section{References}

[1] Yue, F., et al. (2015) Quantitative Trait Locus Analysis for Rice Yield Traits under Two Nitrogen Levels. Rice Science, 22, 108-115. https://doi.org/10.1016/j.rsci.2015.05.014

[2] IRRI (2013) Defining Site-Specific Adaptation Programs in Major Rice-Growing Areas with Specific Vulnerabilities. Technical Report 21, IRRI, Los Baños.

[3] Nelson, S. (2012) Gender and Climate Change Research in Agriculture and Food Security for Rural Development. The CGIAR Research Program on Climate Change, Agriculture and Food Security (CCAFS). Food and Agriculture Organization (FAO), Rome.

[4] Huke, R.E. and Huke, E.H. (1997) Rice Area by Type of Culture: South, Southeast, and East Asia. A Review and Updated Data Base. IRRI, Los Baños.

[5] Fischer, K.S. (2003) Breeding Rice for Drought-Prone Environments. Vol. 1, IRRI, Los Baños.

[6] MOAD (2016) Statistical Information on Nepalese Agriculture (2015/13). Government of Nepal, Ministry of Agricultural Development, Agribusiness Promotion and Statistics Division, Singha Durbar, Kathmandu.

[7] Blum, A. (2011) Drought Resistance-Is It Really a Complex Trait? Functional Plant Biology, 38, 753. https://doi.org/10.1071/FP11101

[8] Kamoshita, A., Chandra Babu, R., Manikanda Boopathi, N. and Fukai, S. (2008) Phenotypic and Genotypic Analysis of Drought-Resistance Traits for Development of Rice Cultivars Adapted to Rainfed Environments. Field Crops Research, 109, $1-23$.

[9] Kumar, A., Bernier, J., Verulkar, S., Lafitte, H.R. and Atlin, G.N. (2008) Breeding for Drought Tolerance: Direct Selection for Yield, Response to Selection and Use of Drought-Tolerant Donors in Upland and Lowland-Adapted Populations. Field Crops Research, 107, 221-231. https://doi.org/10.1016/j.fcr.2008.02.007

[10] Kumar, S., et al. (2014) Identification of Drought Tolerant Rice Genotypes by Analysing Drought Tolerance Indices and Morpho-Physiological Traits. SABRAO Journal of Breeding and Genetics, 46, 217-230.

[11] Raman, A., et al. (2012) Drought Yield Index to Select High Yielding Rice Lines under Different Drought Stress Severities. Rice, 5, 31.

https://doi.org/10.1186/1939-8433-5-31 
[12] Pinter, P.J., Zipoli, G., Reginato, R.J., Jackson, R.D., Idso, S.B. and Hohman, J.P. (1990) Canopy Temperature as an Indicator of Differential Water Use and Yield Performance among Wheat Cultivars. Agricultural Water Management, 18, 35-48. https://doi.org/10.1016/0378-3774(90)90034-V

[13] CDD and ASoN (2017) Rice Science and Technology in Nepal. Crop Development Directorate (CDD), Lalitpur, 976.

[14] Rosielle, A.A. and Hamblin, J. (1981) Theoretical Aspects of Selection for Yield in Stress and Non-Stress Environment. Crop Science, 21, 943-946.

https://doi.org/10.2135/cropsci1981.0011183X002100060033x

[15] Hossain, A.B.S., Sears, R.G., Cox, T.S. and Paulsen, G.M. (1990) Desiccation Tolerance and Its Relationship to Assimilate Partitioning in Winter Wheat. Crop Science, 30, 622-627. https://doi.org/10.2135/cropsci1990.0011183X003000030030x

[16] Bouslama, M. and Schapaugh, W.T. (1984) Stress Tolerance in Soybeans. I. Evaluation of Three Screening Techniques for Heat and Drought Tolerance. Crop Science, 24, 933-937. https://doi.org/10.2135/cropsci1984.0011183X002400050026x

[17] Fernandez, J.C. (1992) Effective Selection Criteria for Assessing Stress Tolerance. Proceedings of the International Symposium on Adaptation of Vegetables and Oth er Food Crops in Temperature and Water Stress, Taiwan, 13-18 August 1992, 257-270.

[18] Fischer, R.A. and Maurer, R. (1978) Drought Resistance in Spring Wheat Cultivars, I. Grain Yield Responses. Australian Journal of Agricultural Research, 29, 897-912. https://doi.org/10.1071/AR9780897

[19] Puri, R., Khadka, K. and Paudyal, A. (2013) Separating Climate Resilient Crops through Screening of Drought Tolerant Rice Land Races in Nepal. Agronomy Journal of Nepal, 1, 80-84. https://doi.org/10.3126/ajn.v1i0.7546

[20] Jat, R.K., Sapkota, T.B., Singh, R.G., Jat, M.L., Kumar, M. and Gupta, R.K. (2014) Seven Years of Conservation Agriculture in a Rice-Wheat Rotation of Eastern Gangetic Plains of South Asia: Yield Trends and Economic Profitability. Field Crops Research, 164, 199-210. https://doi.org/10.1016/j.fcr.2014.04.015

[21] Singh, S.P., et al. (2018) Identification of Drought Tolerant Rice (Oryza sativa L.) Genotypes Using Drought Tolerance Indices under Normal and Water Stress Condition. International Journal of Current Microbiology and Applied Sciences, No. 7, 4757-4766.

[22] Anwar, J., Subhani, G.M., Hussain, M., Ahmad, J. and Munir, M. (2011) Drought Tolerance Indices and Their Correlation with Yield in Exotic Wheat Genotypes. Pakistan Journal of Botany, 43, 1527-1530.

[23] Mau, Y.S., Ndiwa, A.S.S., Oematan, S.S. and Markus, J.E.R. (2019) Drought Tolerance Indices for Selection of Drought Tolerant, High Yielding Upland Rice Genotypes. AJCS, 13, 1835-2707. https://doi.org/10.21475/ajcs.19.13.01.p1778 